364 頭頸部扁平上皮癌において癌抑制型 microRNA-133a が制御する転移抑制機構の解明

○下 崇、花澤豊行、野畑二次郎、吉川直子、鈴木 誉、茶薗英明、櫻井大樹、岡本美孝

千葉大学大学院 医学研究院 耳鼻咽喉科・頭頸部腫瘍学

頭頸部扁平上皮癌のさらなる治療成績向上には、癌細胞の転移メカニズムを明らかとし、その制御方法を見出すことが重 要である。われわれはこれまでに、microRNA-133a(miR-133a) が、1) 頭頸部扁平上皮癌を含む様々な癌において発現が 抑制されていること、2）癌細胞株を用いた機能解析から癌抑制機能を有することを報告してきた。今回の研究では、miR133a が制御する癌細胞転移に関わる分子ネットワークの解明を目的として、転移に関わる夕ンパクコード遺伝子のゲノム 科学的な探索を行った。その結果、転移との関連が示唆されるアクチン関連遺伝子である ARPC 5 や MSN が同定された。 さらに生化学的な解析から、これらの遺伝子は、miR-133aによって直接制御されていることが確認できた。また、これら 遺伝子について siRNA を用いてノックダウンすることにより、癌細胞の浸潤・遊走が顕著に抑制された。今回の解析結果 により、癌抑制型 miR-133a が制御する頭頸部扁平上皮癌の転移抑制機構の一端が明らかとなった。

\title{
365 機能性ペプチド細胞内導入システムを用いた新たなる頭頸部癌治療の探求
}

○土屋吉正、西村邦宏、伴野真哉、池田篤彦、小川徹也、植田広海 愛知医科大学 耳鼻咽喉科

【背景】頭頸部癌治療の主体は抗癌剤・手術・放射線である。しかしこれらの治療でも制御できない症例が存在する。 頭頸部癌は癌抑制遺伝子産物 p16INK4a の発現低下が多い。p16INK4a を細胞内に導入しその機能が回復できれば、新たな る治療となりうる。【方法】頭頸部扁平上皮癌細胞株 UM-SCC-23、UM-SCC-6、UM-SCC-81B を用いた。Western Blotting 法およびPCR 法にて p16INK4a および他の因子の発現を確認した。p16INK4a 発現欠損細胞に対する機能回復のた め改良型輸送体 Wr-Tによるペプチド・タンパク導入システムを用い,p16INK4a 細胞内へ導入した。【結果】すべての 細胞株で p16INK4a の欠損を確認した。これらの細胞株に p16INK4a を Wr-T で導入し、細胞増殖抑制効果を確認した。【ま とめ】 p16INK4a の欠損した頭頸部癌に対して p16INK4a の導入が抗腫瘍効果を発揮する可能性が示唆された。今後さらに 新たなる頭頸部癌治療として探求していく。

\section{6 頭頸部癌細胞株における microRNA200family と転移機能について}

○玉川俊次、Beder Levent、矢田和也、戸川彰久、保富宗城、田村真司、山中 昇 和歌山県立医科大学 医学部 耳鼻咽喉科・頭頸部外科

頭頸部癌における頸部リンパ節転移の状態は生存率を左右する重要な因子であり治療選択に大きく影響する。近年、18～ 25塩基の蛋白をコードしない低分子量 RNA：マイクロ RNA が発見された。マイクロ RNA は標的 mRNA の 3’ 非翻訳領域 に結合し分化、増殖などの遺伝子発現を様々な形で調整する。以前より ZEB1、SIP1 などの遺伝子は E-Cadherin の発現を 抑制し上皮間葉移行を促すことが示されている。ある種のマイクロ RNA は ZEB1、SIP1 を抑制し上皮間葉移行と関連する ことが報告されている。われわれはマイクロ RNAをバイオマーカーとした転移のリスク診断への応用を考えている。頭頸 部癌細胞株を用いて microRNA200family、ZEB1、SIP1、E-Cadherinの発現の関係をリアルタイムPCRにて解析した。 microRNA200family と E-Cadherin の発現には正の相関を認めた。さらに、microRNA200family 頭頸部癌細胞株にトラン スフェクションし上皮間葉移行関連遺伝子発現の変化をリアルタイム PCR で解析し統計学的に有意な変化を認めた。細胞 表面蛋白の変化、転移機能に及ぼす影響についても検討した。

\section{7 骨形成蛋白（BMP）を用いた動物側頭骨の再生}

○杉本 晃、岡本美孝

千葉大学 医学部 耳鼻咽喉・頭頸部外科

骨形成蛋白（BMP：bone morphogenetic protein）は骨再生を促進する成長因子の一つである。脱灰骨基質を皮下や筋肉 内に移植し異所性骨誘導現象を発見され、骨基質中に骨形成を担うタンパク性因子の存在を示唆され BMP と命名された。 現在 BMP の臨床応用が始まっている。乳突部を含む側頭骨は含気骨に分類され、内部に蜂巣状の空洞や感覚器等を有して いるが、現在のところ解剖学的構造の特殊性もあり側頭骨でのBMPがどのように働くかについては十分に分かっていな い。BMP を用い側頭骨での骨欠損部位に任意の大きさや形の骨再生が可能になれば、今後の耳科手術で有用でないかと考 え、モルモットを用いた側頭骨に抢けるBMPを用いた骨再生の検討をした。実験は、鼓膜正常のハートレイ系白色モルモ ットを使用した。側頭骨を削開し、削開部位にBMP と担体を埋め込む。一定期間後この操作部位を micro CT 用い評価 し骨組織の形成を確認し、その成熟過程を実験し、評価した。今後の骨組織の再生を任意に誘導する技術を開発することに つなげるため、文献的考察とともに提示する。 
○山田啓之、羽藤直人、暁 清文

愛媛大学 医学部 耳鼻咽喉科

MED-EL 社の人工中耳 Vibrant Soundbrige は、2011年11月より本邦での臨床治験が開始され、臨床応用が期待されてい る。この人工中耳は体外部のオーディオプロセッサと体内部の受信コイル、振動子 (floating mass transducer : FMT) から なり、もともと感音性難聴に対して開発され、FMTを耳小骨に装着していた。しかし近年、混合性難聴や伝音性難聴にも 適応が拡大され、正円空に FMT を装着し、直接、内耳を振動させる方法が報告されるようになってきた。また、それに伴 いMED-EL社より FMT を装着させる Coupler（取り付け部品）が開発された。しかし、Coupler を付けた FMTの伝音効 率について検討された報告はない。そこで今回、われわれは新鮮摘出ヒト側頭骨を用いてCoupler を付けた FMT の伝音効 率を測定したので報告する。測定は側頭骨に乳突削開、下鼓室開放術を行い、FMTをCoupler と伴に中耳に扱入し、レー ザードップラー測定装置を用いて行った。

\section{Laser Doppler Vibrometer による鼓膜および耳小骨の振動解析}

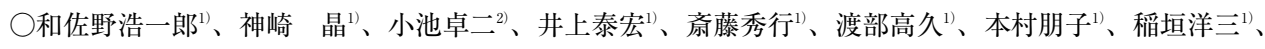
若林聡子' ${ }^{1)}$ 小川 郁 ${ }^{1}$

慶應義塾大学 医学部 耳鼻咽喉科 ${ }^{1}$ 、電気通信大学大学院 情報理工学研究科 ${ }^{2}$

Laser doppler vibrometer(LDV) により鼓膜および耳小骨の振動を非接触かつ非侵襲的に測定可能であることを耳科学会 のシンポジウムで報告した。

その後、未固定御遺体や中耳疾患のない健常人の耳における鼓膜および耳小骨振動を測定・解析したので報告する。

LDV を用いることで様々な周波数の音を発生させながら任意の部位の鼓膜振動を解析し、鼓膜のどの部位が最も振動し ているのか、周波数別に特異的な部位があるのかなどを解明できる。そのデー夕を用いて効率のよいコルメラ留置部位・材

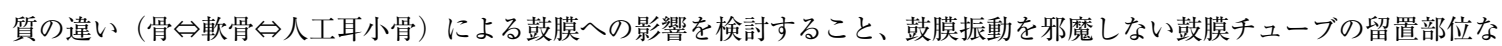
どを改めて検討すること、鼓膜異常のない伝音難聴（耳小骨奇形や耳硬化症など）の診断に際しティンパノグラム以上の情 報を得ることができるであろう。

今後も、データを蓄積することで耳科診療における質の向上を図っていきたい。

\section{中耳貯留液中の高ペプシノーゲンは感音難聴のリスクファクターか？}

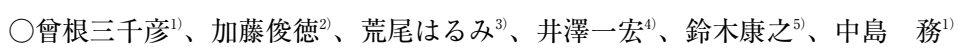
名古屋大学大学院 医学系研究科 頭頸部 - 感鸴器外科学 耳鼻咽喉科 ${ }^{11}$ 、加藤耳鼻咽喉科 ${ }^{2} 、$ 荒尾内科耳鼻咽喉科 ${ }^{3)}$ 、井澤医院 ${ }^{4)}$ 、鈴木耳鼻咽喉科 ${ }^{5)}$

胃食道逆流による成人渗出性中耳炎（OME）の診断には、貯留液中のペプシノーゲン（PG）測定が有用であることを報 告してきた。酸とペプシンが喉頭や耳管傷害の主因であることは動物実験からも証明されている。今回、逆流液中の高 PG が感音難聴のリスクファクターとなるうるかの検討を行った。PG 測定をした誘因不明の OME 245例中、評価可能な純音 聴力検查結果を有する一側性 $\mathrm{OME}$ 症例から高 $\mathrm{PG}$ 群 $(500 \mathrm{ng} / \mathrm{ml}<)$ と低 $\mathrm{PG}$ 群 $(<50 \mathrm{ng} / \mathrm{ml})$ 各23例を抽出した。各症例 の患側㧍よび健側の $0.25 \mathrm{kHz}$ から $4 \mathrm{kHz}$ までの 5 周波の骨導閾值について評価した。全周波数で 2 群間の患側と健側の骨 導閾值に有意差はなかったが、高 PG 群では $0.25 \mathrm{kHz}$ の患側骨導閾值が健側に比し有意に上昇しており、15dB 以上の閾値 上昇例も高率であった。この傾向は特に高齢者に認められた。逆流による OME 症例では鼓膜換気チューブ留置のみでは不 十分であり、生活指導やプロトロンポンプ阻害剤の投与が必要であると考えられた。

\section{1 ブロー液の安全かつ効果的な使用法についての実験的研究}

○菅村真由美 ${ }^{1}$ 、山野貴史 ${ }^{122)}$ 、樋口仁美 ${ }^{11} 、$ 中川尚志 ${ }^{1)}$ 、森園哲夫 ${ }^{3)}$

福岡大学 耳鼻咽㑨科学教室 ${ }^{1)}$ 、福岡大学筑紫病院 耳鼻咽喉科 ${ }^{2}$ 、西福岡病院 ${ }^{3}$

（目的）われわれはブロー液の内耳毒性について、動物モデルを使用し報告してきた。今回は原液のブロー液、2 倍希釈 ブロー液、 $\mathrm{pH}$ を調節したものを比較し内耳毒性の発現および殺菌作用の違いについて検討を行った。(対象と方法) ハー トレー系モルモットを使用。ブロー液は手稲溪仁会マニュアルにそって作成したもの（pH3.5）と、生理食塩水で 2 倍希釈 したブロー液、および標準緩衝液 (ホウ酸塩) で $\mathrm{pH} 4.5$ に調節したものを用いた。蝸牛複合電位 CAP を測定した後に薬剤 を中耳腔に投与。30分後に中耳腔を洗浄し再度 CAP を測定。細菌学的検討はディスク法での検定を行った。(結果と考察) pH3. 5 ブロー液は30分投与で CAP の闇值上昇があったが、 2 倍希釈したものと $\mathrm{pH} 4.5$ に調節したものでは認めなかった。 殺菌作用については pH3.5 と 2 倍希釈にはすべての菌種で殺菌作用を認めたが、pH4.5 では緑膿菌の標準株でのみ認め た。ブロー液を生理食塩水で 2 倍希釈する方法は殺菌効果を維持しつつ安全性を高める上の一つの方法であると思われた。 


\section{2 好酸球性中耳炎モデル動物作製の試み}

○西澤尚徳、松原 篤、白崎 隆、新川秀一

弘前大学大学院医学研究科耳鼻咽喉科学講座

近年、好酸球性中耳炎の診断基準が提唱され、疾患に対する検討が進められているが、その詳細はまだ不明な部分も多 い。その病態の解析を進めるため、今回われわれは、新たに好酸球性中耳炎モデル動物の作製を試みたので報告する。

Hartley 系モルモットを対象として、卵白アルブミンによる全身感作を行った後に、鼻腔・中耳粘膜への抗原による局所 刺激を最長 4 週間まで継続して行った。その結果、中耳粘膜は刺激により肥厚し粘膜内には好酸球の浸潤が認められた。ま た、抗原刺激の期間が長いほど粘膜の厚さと好酸球浸潤はともに有意に増加しいていた。これまでにわれわれは、好酸球性 中耳炎の症例の中耳肉芽には喘息リモデリング関連因子である Periostin が局在することを報告してきたが、今回作製した モデルの中耳粘膜に扔いても抗 Periostin 抗体に対する染色性が認められ、粘膜肥厚の機序に喘息のリモデリング同様の機 序が関与する事が示唆された。(本研究は佐賀医科大学医学部分子生命科学講座、出原賢治教授との共同研究である)

\section{3 メニエール病モデル動物における V2R 拮抗的阻害薬の内リンパ水腫軽減効果に関する検討}

○江上直也 ${ }^{1)}$ 、柿木章伸 ${ }^{1)}$ 、坂本幸士 ${ }^{1)}$ 、西岡利恵 ${ }^{2)}$ 、竹田泰三 ${ }^{3)}$ 、兵頭政光 ${ }^{3}$ 、山岨達也 ${ }^{1)}$

東京大学＼cjkstart医学部耳鼻咽喉科12、土佐市民病院耳鼻咽㑨科 ${ }^{2}$ 、高知大学＼cjkstart医学部耳鼻咽喉科 ${ }^{3}$

【目的】メニエール病の病理組織学特徵は内リンパ水腫であり、従来より実験的、臨床的報告により内リンパ囊における 内リンパの吸収障害が内リンパ水腫の一因として考えられている。一方、様々な実験的、臨床的検討の結果、内耳液の恒常 性維持に抗利尿ホルモン（バゾプレッシン；VP）を介した水代謝機構が介在し、このシステムの立進が内リンパ水腫形成 に関与していると考えられている。今回、われわれはVP のレセプターであるV VR の拮抗的阻害薬を用い、実験的内リン パ水腫動物に対する水腫軽減効果について検討した。【方法】ハートレイ系モルモットを用い、内リンパ囊閉塞術施行後、 4 週間、自由飲水にて飼育した動物に V $2 R$ 拮抗的阻害薬である OPC-31260 および OPC-41061 そそれぞれ 5 日間、連日経 口投与した。内リンパ水腫の程度について蝸牛、球形囊において組織学的に検討した。【結果】V2R 拮抗的阻害薬投与群に おいて水腫軽減効果を認めた。このことより内リンパ水腫形成に VPを介した水代謝機構が介在している可能性が示唆され た。

\section{4 シスプラチンを用いた化学放射線療法が骨導超音波聴力に与える影響}

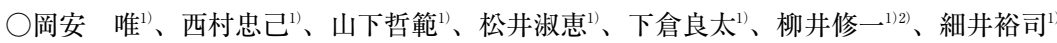
奈良県立医科大学 耳鼻咽喉・頭頸部外科 ${ }^{11}$ 、東京都健康長寿医療センター2)

骨導超音波の知覚メカニズムについて、外有毛細胞による能動的な基底板の振動の増幅を介さずに、超音波自体の基底板 の振動により内有毛細胞が刺激されることで知覚されるという仮説が報告されている。本検討では超音波知覚に㧍ける外有 毛細胞の関与について調べるために、外有毛細胞優位の内耳障害がおこるとされているシスプラチンを用いた化学放射線治 療を行う患者 20 名 40 耳に対して、治療の前後の純音聴力検查、高周波聴力、骨導超音波聴力を調べた。治療後には American Speech-Language-Hearing Association の基準で 25 耳 $62.5 \%$ に聴力障害を認め、超音波知覚に関与すると考えられる高周波 域の可聴音の聴力は有意に悪化していた。一方、骨導超音波の聴力については悪化は認めず、逆に有意な改善を認めた。こ れらの結果は外有毛細胞の機能が骨導超音波知覚に関与していないという仮説を支持する結果であると考えられた。

\section{5}

\section{ゼブラフィッシュ側線を用いた有毛細胞障害に関する抗癌剤のスクリーニング}

○広瀬敬信、菅原一真、山下裕司

山口大学大学院医学系研究科医学部耳鼻咽喉科学分野

抗癌剤の副作用として聴力障害を引き起こす事はよく知られている。ゼブラフィッシュは安価に飼育でき、多く産卵する ため、多数の薬物をスクリーニングする上では適した動物である。その側線の神経小丘には有毛細胞があり、内耳と似た構 造である。この研究の目的はゼブラフィッシュを用いて内耳毒性薬物を見つける事で、8 8 種類の抗癌剤のスクリーニングを 行った。

生後 5-7 日目のゼブラフィッシュを用い、生きたまま蛍光顕微鏡にて観察した。結果は、カルボプラチンを除いた既知 の聴力障害を引き起こす抗癌剤をはじめ、いくつかの薬剤に有毛細胞障害がみられた。次に、通常抗癌剤は相乗効果を期待 して併用して使用される事が多いが、有毛細胞にも同様に相乗効果の有毛細胞障害を引き起こすのではないかと考えた。結 果は幾つかの組み合わせに相乗効果のある障害が見られた。

以上より、ゼブラフィッシュの側線有毛細胞を利用する事で、抗癌剂の内耳障害を引き起こす薬剤を同定する、また相互 作用を評価するのに有用であると考えられた。 